\title{
Creating Opportunities for Positive Connections with Elementary Students
}

\author{
Ken Reimer \\ Faculty of Education, University of Winnipeg, Canada
}

\begin{abstract}
Manitoba elementary school classroom teachers $(n=8)$ participated in a think tank to investigate what they do to connect with students. The teachers in the study believed that connecting with their students was crucial. In many ways, the participants attempted to connect with their students like caring family members. They saw benefits in connecting as early as possible with the student, their homes, and family members. One finding of the study was that elementary teacher practices for teacher-student connection align with the Norwegian term 'koselig'.
\end{abstract}

\section{Introduction}

For teachers, connecting with students is a fundamental component to achieving school success. Nasir, Jones, and McLaughlin posit that, "schools play an important role in structuring experiences of connection or disconnection for students", and that, "students who were connected both interpersonally and institutionally had higher grades and graduation rates" [1, p. 1755]. Davis asserts that, "a positive relationship with the teacher can act as an additional resource for a student while a difficult relationship may act as obstacle to academic success" [2, pp.431432]. Hamre and Pianta [3] believe that, "students' relationships with teachers are fundamental to their success in school, and as such, these relationships should be explicitly targeted in school-based prevention and intervention efforts. Forming strong and supportive relationships with teachers (also) allows students to feel safer and more secure in the school setting, feel more competent, make more positive connections with peers, and make greater academic gains" (p.59).

\section{Connecting with elementary students}

Research supports the notion that teacher-student connections are most crucial as children first enter the school system. Baker [4] asks, "Do teacher child relationships matter in the development of children's competencies during the elementary-school years? They seem to matter a great deal for young children" (p.211). Davis [2] states that, "the relationship that develops between a student and teacher can be a powerful motivator. This is particularly true of elementary school students" (p.431).

The question this study asks is, "how do teachers make connections?" Hamre and Pianta [3] note that, "Student-teacher relationships develop over the course of the school year through a complex intersection of student and teacher beliefs, attitudes, behaviors, and interactions with one another (p.59). As elementary teachers usually are responsible for a homeroom class of 20 to 33 children [5], this may be easier said than done, and requires further examination. As elementary teachers tend to be with the same group of students for most of the school day, it is not an exaggeration to say that many children might spend more of their weekday waking hours with their classroom teacher than their parents.

\section{Methods}

This (2018) study was conducted as an attempt to learn from elementary teachers the strategies and approaches they use to connect with elementary students to increase the probability of them being successful in school. This study had schoolteachers $(\mathrm{n}=8)$ assemble in a think tank and share ideas on how they tried to accomplish creating these connections with their young learners.

\subsection{Procedures}

After receiving approval from the ethical review board at the University of Winnipeg, I obtained consent from a Manitoba school division and several school administrators to conduct my study. Teachers were given a letter outlining the nature of the study and were required to give written consent prior to the commencement of the study. Teachers were provided with an option to participate in the study. Teachers who were interested in participating were invited to contact me. Once I received written consent from these teachers, they were invited to assemble together in order to form a "think tank" type of focus group [6]. It should be noted that all conversations and responses in the think tank were collected in aggregate, so that no one participant was singled out by the researcher when the data was shared in the study's final results portion of the study. 


\subsection{Participants}

The teacher participants $(n=8)$ were from the same school division, and were currently teaching in one of two elementary schools. The teachers each taught in academic classrooms which ranged from grades 1 to 6 . All had experience teaching in multiage classrooms. Six participants agreed to gather together for an after-school meeting, while two participants preferred to individually meet with me. For this think tank, the starting question was always, "What do you do to connect with students in your classroom?" All agreed that this was a suitable question to ask.

\subsection{Data Collection and Analysis}

All meetings were audio taped. My research assistant and I reviewed all the transcripts and notes from each of the think tank assemblies, and asked a research assistant to independently do the same. We then agreed upon several themes that we believed were an accurate depiction of what emerged from the transcripts. I sent out the list of themes to the participants. There was no disagreement with any of the themes that I chose. I completed a study report, and sent each participant a draft for review. Based on feedback from participants, some minor edits that focused primarily on grammatical issues were made. Once this was completed, I sent the final report to the participants.

\subsection{Findings}

Next, I analyze one of the emergent themes that we agreed upon as a collective group in order to determine their significance with respect to my research question, and to prior research, implications for practice, and possible future research. To benefit the reader of this study, I inserted many direct quotations from participants, but removed words they repeated and/or used terms such as "um" or "like" as they shared their thoughts.

One of the themes that emerged from the study was that the participants attempted to connect with their students using many creative approaches. They also placed significant emphasis on connecting with their students like caring family members. They saw great benefits in connecting with the student, their home, and family members as early as possible. In many ways, participants hoped that students would feel like their classrooms felt like a second home.

\section{Creative Connections}

Teachers highlighted many creative ways in which they connected with their young learners.
They emphasized the importance of greeting each child as they entered the classroom ("You want to make everyone feel welcome"). Many spoke about joining in to play with students in the classroom and during recess ("I have used time to connect, to play and connect. I do a lot of it at school"). Teachers shared how reading a book together provided an excellent opportunity to connect ("Always have a book on the go with the kids" and, "A great way to connect with kids. You can't beat it."). One teacher spoke about taking the time to serve as the student's scribe for their thoughts and activities, as many were not yet able to write ("That's also a connection with the children in kindergarten. When I used to write down their stories, they're trusting me with their words"). Some teachers took photographs of students engaged in a variety of activities, which were later posted throughout the classroom or given to students to take home ("The kids look for pictures of themselves, so they notice right away when you bring them in"). A few teachers had their pet dogs come visit their classes, to the delight of many children ("Dogs love everybody!"). Some teachers attended their students' after school sporting events, musical recitals, and theatre productions in an attempt to connect better with the students and family ["(I) was invited at Christmas to three different dance recitals, and (now) I have such a great parent connection"].

Often, opportunities to connect seemed to arise spontaneously. Teachers recognized the need to be ready to take advantage of these unplanned moments. When I asked one participant how s/he determined which were the most effective strategies to connect, s/he offered, "I think eventually you will stumble upon what research says works." One participant noted, "If you have good intentions and you make wide-awake decisions and you try to do the right thing and you are really thinking of what you are doing, you end up kind of doing what the research says to do.”

\subsection{Making Time to Connect with Students}

The first priority each day should be to connect with students. Teachers indicated the importance of warmly greeting and connecting with their young students as soon as possible. One teacher commented, "We do it right from 8:30 in the morning when the kids are in the hallway just saying hi to them or welcoming them into the school. I know we are very big on that in September, because you want to make everyone feel welcome and you are getting to know the students. They are getting to know you, and I think that truly helps."

One teacher affirmed the importance of connecting with students before the school day even begins, as for some students it can determine how the course of the day can go. She recalled, "Where I had 
this one student that being at the door to say hello to him in the morning, or greeting him by name, sets his tone for the day. (One day) I was photocopying, and I was not back to my room by the time the bell went. He thought there was a substitute, and so he is already flopped outside the classroom door, shutting down, right? I walk around the corner and he just turns right around and doesn't know what to do with himself because he can't quite get out of his funk. But he sees that I am there to say hello, and then we can move on with our day."

September can be tough month for young students. One teacher spoke about the fact that connecting does not happen easily. The teacher stated, "The beginning of the year, you do everything you can to connect with the kids from the get-go and then, it takes a while. I come home in September, and I go to my partner and say, "Boy, this is tough", and (s/he) says, "You say that every year"...It just takes time... to build. There is no shortcut. You got to be down on your knees, looking into kid's eyes. You got to be making those little jokes. You got to be making the little connections and writing back to them and hearing from them and getting to know them."

Teachers in this think tank shared an example of how a school-wide initiative can helps connect teachers with new students months before the start of the school year prior to the commencement of the school year. One teacher expressed, "In May prior to the new Kindergarteners coming into the school, we do an open house night, where the kids actually get onto a school bus at [a local] Shopping Centre to take their like first ride on a school bus." Another teacher described how the evening went for these young children and their families.

The principal meets them at the school bus and then they are brought to the school. All the teachers that they are going to have for their kindergarten year are at the school. They greet them and then they go to ten different stations throughout the school. So, they come to the gym for a ten-minute session, they go to the music room, they go to both kindergarten teachers, I think, library, and a couple of other ones. And then, it's an hour and then they have a snack, and a song, they get a book at the end of it, and they get back onto the school bus and then they go to [the] Shopping Centre again. So, it is getting them into the school, they get to meet their teachers.

One teacher highlighted a more flexible time during the school year when connections seemed to happen. The teacher said, "After their first report card, you have this four or five weeks before Christmas break and it's kind of a cool time of year. I've always said it because you are not thinking about report cards because you are going to have this two-week break. And it's not like the time gets lost, but it does take a lot of pressure off from the report cards."
According to the participants in the think tank, it appears that the month prior to Winter Break was an important time for school administrators to refrain from making too many demands on teachers and classrooms. When I asked for a more specific time frame, one teacher shared, "November 20 till the break...Like four or five weeks...There [are] no deadlines because we are just going to have four or five weeks until a holiday, and then we are going to come back in January and then there'll be some deadlines. But, there is this deadline list date and there is so much time for projects and for group...It seems like you find seasons, almost where (the) start of the year is really important time and right when their first report card. It almost seems like after that is done, there is this [magic time to connect]."

Therefore, school administrators might do well to reduce school-wide demands on teachers and students during this time. With the added pressure often placed on elementary schools during this time of year (such as holiday concerts), it appears even more crucial for senior divisional administrators to reduce the reporting demands of school administrators during this time of year.

\subsection{Connecting Through Clubs, Teams, and Extra-curricular Opportunities}

Although extra-curricular activities are limited when compared to high schools, teachers saw great value in seeking out opportunities for them. One teacher shared, "You learn something about [your students] through extra curriculars, something completely different." One teacher expressed how starting an embroidery club provided a moment to connect with a student and a family member. The teacher stated, "There was one student who I probably would have never thought would have had the patience for [embroidery]. [The student] came and was like, 'My Grandma taught me how to do this', and she did it perfectly. Yesterday I learned something totally new about her. [I asked her], 'Does your Grandma want to come and teach us?' Because we are just learning how to do this, we are learning alongside the kids. I think [the grandma] is the expert, it would be awesome if she came out and there is the connection."

As many young students are bussed to school, or cannot stay as late as young people in high school, there are many restrictions to conducting extracurricular activities with elementary students. Still, teachers in this study expressed how extra-curricular activities presented leadership opportunities for children. Regarding extra-curricular activities, one teacher noted, "We have a lot of student-led ones. The older kids love hockey, especially the boys. So, they are in charge of making the teams, getting the sign-up going. It is totally them and then they have a supervisor come in with them. A token teacher." One 
teacher really liked, "letting [students] take ownership of that, I find that they really like it and engages them in even more in it." Another teacher added that for grade one and two students, "We have yoga club which is also run by some grade five girls, who have been doing an amazing job with it actually... They teach it to the kids and they are very good at it."

Teachers in the study shared a variety of different extra-curricular clubs and activities for students to connect with, including coding, tap club, embroidery club, running club, dodgeball, badminton, and soccer. These opportunities were offered typically at $8: 30$ am or during lunch period. Still, it was difficult for teachers to offer a multitude of opportunities, "Because a majority of our kids take the bus, it is harder to do the before and after school clubs. So, a lot of it is [also] at our recess times."

\section{3. 'Home Away From Home'}

Some teachers wanted the classroom to feel like a second home, and their teacher and classmates to feel like a second family. One teacher synthesized the thoughts of many participants in the study when (s)he stated, "I want the children to feel like this is their home away from home." This teacher later exclaimed that in his/her school, "we are known as the room [room number withheld] family!" When I asked him/her how this was accomplished, (s)he described the first time (s)he might meet a child coming to his/her classroom by saying, "I set up the classroom in such a way that it doesn't look like a typical classroom. I have a big carpet space, I have a lot of intricate little areas in the classroom where kids can go and feel either safe, if they are having a hard time, or there's little toys or figurines that they can go play with if they need a break or stuff." The teacher added, "I want [students] to know that I am focused on them."

One teacher stated, "I have a word wall in my classroom and in the beginning of the year, I had all their names up already. The kids that I had last year already expected it, but the ones coming in [said], 'my name is in the room already', [and] they thought that was so neat. I think they like hearing and seeing their names."

One teacher highlighted the importance of students seeing more than just their names in the classroom, stating, "I have some pictures too. Pictures in the classroom, a digital frame going out and we have it on our smart board. The kids look for pictures of themselves, so they notice right away when you bring them in. They are looking for their name or they are looking for their picture."

For one teacher, displaying class pictures was a form of, "constant community building that builds connections between us and the kids but also the kids with each other, to get more of a family." The teacher thought this had a significant effect for students, noting, "There are kids in care that don't have family photos." When she realized this, the teacher, "sent home the photo albums of the whole year for all the kids. Yes, you know like those Grandma Brag Books."

\subsection{The importance of touch}

Some participants in this study spent a significant part of a think tank session sharing their thoughts on the importance of touch in connecting with young student. When one teacher bravely stated, "I don't think this conversation would be complete without mentioning the physical component of touch", other teachers nodded in affirmation and expanded on the subject.

One teacher noted, "Many of the kids you had last year and you walk in and you were on the floor with like three kids hanging off of you, sitting on your lap, leaning up against you, right? I have a couple of your kids and that physical touch, when they come in the door and they just happen to lean up against me. They just want that hug, right? You are naturally doing that, but that made them so comfortable with you. If I wasn't a touchy-feely teacher, I wonder how that relationship would have gone with this year. But they need it, they need it when they are working. I'm rubbing their back or I am scratching his head. Just walking around and making physical touch, right? The students that left, every day when he left, he wanted a hug, and he wasn't with his birth mom. I just always felt, he's never getting hugged." Another teacher added, "So, when you are down on the floor playing...they'll just come and just...lean up against and nuzzle up to you...sit on your lap."

One teacher acknowledged the delicate balance of carefully meeting students' needs for touch, saying, "You have to be really appropriate and careful with that." Another teacher shared, "That's the one thing they don't tell you in a textbook. Don't touch. I remember in a university course. Don't touch your kids, don't hug them. And you come [into the school] and I have to hug these kids. You have to let them hug you." A teacher then interjected, "I think about it from a mom's perspective, how often I touch and hug and squeeze my own kids. It's like how many of these kids just, they need that, right? And I guarantee, if I've not made that kind of physical connection in the morning with some of these kids. [In] the afternoon, I can predict how it is going to go. They feel disconnected with me...without a physical touch."

One teacher said, "I asked (my students), 'What are you doing in the evening, when you go home from school?' And, it's nothing to do with family time. [Some students respond], 'I went with so and so, or I went with mom, or I went with foster mom, 
or whatever. For many of them, there is no time where they are together doing something where there would be physical touch. I look at that and I'm like, these kids are not getting any kind of that, 'I believe in you. I care about you.", One teacher stated, "You are not going to get academically further without first reassuring them that you are here for them. I have two kids in someone else's class (and) every time we pass them in the hall, they need a hug from me. And it's huge."

One teacher poignantly shared a story that emotionally impacted the group, saying, "I found out that one of the kids was taking off their gloves, before they came in so their hands would be cold, so I would hold their hands. Yes, they just want, just that touch of my hand, and your hands, to hold hands. That's crazy. I'm just like, 'Wear your mitts?' I'm like so mad, right? I'm like, 'wear your mitts, you have mitts'. One student said ['wear your mitts', and] she said, 'I don't want to'. And then she whispered and she said, 'I don't want to because Mrs. [teacher's initial withheld] warms them when I get in the classroom". Other teachers shared similar experiences.

\subsection{Dogs}

Some participants wanted to share the benefits of bringing pet dogs into the school. One teacher commented on how bringing their dog into the classroom provided a connecting opportunity with a hard-to-reach student. The teacher said, "I had one particular student who was really tough to make connections with, but he had a dog and he looked at the pictures I had on my desk of my dog in a picture frame. So, we just started talking about that... when we were trying to hook this kid into staying into the classroom." One teacher added, "It is just something that the kids remember. I find it's like a calming thing for all kids, and even other kids now from other classes know his name. [They] say hi to him in the hall and everything."

Dogs may be able to promote curricular outcomes and opportunities to collaborate. One participant explained, "Our kids [now] do 'See Spot Read' which is through the Humane Society. They have been going once a week, and they go and they have a dog that they read to every single week and build a relationship. It eliminated the pressure of having to read with another human."

Dogs also have potential to promote positive behaviour. One teacher shared that dogs in the classroom also promote responsibility and appropriate behaviour. The teacher stated, "It even gives responsibility to some students." She described how students all shared responsibility for providing the dog with food and water.

\subsection{Connecting with the family}

The participants also saw great benefits in connecting with the student, their home, and family members as early as possible. One teacher shared the importance of connecting with future students through their siblings. She stated, "What's so fun is that when you have a sibling, so say I taught the older child and then the sibling comes in. It's so much easier for me to just get right in and connect with them." When I asked how she accomplished this, she answered, "The door is always open. Whenever we have a fieldtrip or invite parent volunteers in...the younger siblings are invited as well. So, they get comfortable with the class."

School administrators who recognized the importance of siblings and teacher connections were appreciated. One teacher stated, "Our admin. has always...we try to keep families with the same teacher. It makes sense."

Connecting with parents of students was generally regarded as a "best practice" by all the teachers in the think tank. One teacher described how she dealt with a situation where, "the child is not engaging and the parent has disconnected from the school as well." She decided that if connections were not happening at school, then she needed to make the connection outside her workplace and workday. She stated, "I go to the kids hockey games on the weekends and I sit with that mom. I have three boys that are on the same team and they always play together. So, it is a win-win for me to go, because I am seeing three of my kids at one shot, but I am also sitting with parents." By making a conscious effort to sit with the child's mother, there have been direct benefits to the parents' child. The teacher explained, "I always sit with her more often and this year, we have got every [permission] form back. That has not happened before, but we are getting every form back. When I text her during the day - you know, 'this is the issue right now' [or] 'we are struggling' - she texts me back."

Some teachers shared how their school connects with families prior to the commencement of the school year. In May, prior to the school year, "Kindergarteners coming into the school, we do an open house night, where the kids actually get onto a school bus at [a local] Shopping Centre to take their like first ride on a school bus." The interesting approach that this school takes is to ensure that parents join their children on the bus. One teacher explained, "Their first ride is with their parents... Then their parents also have a chance to see what it is like and meet all the teachers they will be seeing that year." One teacher further elaborated, "The principal meets them at the school bus and then they are brought to the school. All the teachers that they are going to have for their kindergarten year are at the school." After each future student is provided 
with an abbreviated 'first day of school' experience, "they get a book at the end of it, and they get back onto the school bus and then they go to [the] Shopping Centre again. So, it is getting them into the school, they get to meet their teachers."

This event had benefits for teachers too. One teacher shared, "Teachers are able to see who's coming up. And you can of start preparing. You quickly find out who might be a little bit more energetic than others. Or, maybe who's not ready for school yet."

One interesting point that some teachers highlighted was how the ability to connect with parents was easier when children were dropped off directly at school by parents, as opposed to being bussed. One teacher shared, "So many of our kids take the bus, I feel like I have a better relationship with the kids that do get dropped off because, I see their parents more often."

Some teachers responded to this issue by using cell phones to connect with parents. One teacher noted that for, "the kid in the morning that doesn't have their agenda, I have my phone [and say to the parent], 'Can you please check underneath so and so's bed, she thinks she left it there. Throw it in her backpack for tomorrow' - done. [Or] someone doesn't have gym clothes - 'Can you just get gym clothes for [your child as] we are doing gym in two more days'. I am sending these [texts] throughout the day constantly."

The use of cellular phones created some issues, and participants took time to discuss the importance of boundaries. One teacher cautioned, "you don't [want to] have parents texting all hours, like Sunday at night, when you don't want to be bothered." Teachers continued to express how having phone connection enabled positive interactions. One teacher stated, "I just have had no parent ever abuse it. Comments back are so positive. Then, at student conferences, [parents] are like, "'Oh, I remember that'... because I have taken a picture of it three months ago. I'm going to send [items like] pictures home in hopes that you will be able to show them to your child, because I am trying to build opportunity for families to talk with their kids."

After hearing the many benefits of connecting through texts, I asked teachers if connecting with parents on social media platforms ever presented awkward or uncomfortable moments. One teacher confided, "I have known a friend who's had a parent try and add them on Facebook to the point where they couldn't have a visit anymore. I think the fact that you become too accessible, then people maybe become too comfortable and lines can get blurred." One teacher thought that for some parents, the "level of comfort has increased because I'm accessible and we're to be on the same page and you know, but...we're not best friends."
Participants spoke about the complexity of many homes and families. During one think tank session, a teacher exclaimed, "Home life and families are complicated." One teacher shared, "I just like feel a little sad because I have students that don't know where their parents are." Another teacher shared how a new role in learning support showed this, saying, "I now deal for the first [time] in my career with children in care every single day." This teacher added that she now connects, with, "the social worker, classroom, parents and the biological parents, and so many moving parts with them." This teacher spoke about how impressed she was with so many classroom teachers and how they often did everything they could to "bring in all the adults that are in their [students'] lives."

\section{Discussion and Analysis}

\section{1. "Home Away From Home" and Koselig}

Teachers in the think tank never offered one "magic" solution (or panacea) to connecting with children. Rather, they provided many examples of how they creatively connected with young learners. They described classrooms adorned with cozy carpets, photographs of classmates, inviting play areas, and sometimes even a pet dog. Teachers explained the significance of connecting with their students early and often, and the importance of warm greetings and interactions. They wanted their classroom to feel like a "home away from home", and themselves to be viewed as caring family members.

Creating a homey atmosphere in the classroom seemed to connect with the philosophy of "koselig". Loosely defined, the Norwegian word koselig (pronounced "koosh-lee"), means "coziness" [7]. Nikel [8] defines it as, "koselig is a feeling: that of coziness, intimacy, warmth, happiness, being content" (para.7).There are some crucial components to how something is made koselig, as it is typically found by enjoying the company of others or being in nature. Koselig (sometimes referred to as simply 'kos) is essentially "about fellowship, gathering together, and sharing experiences" [9, para.25]. Garvey [10] posits that, "Koselig is experienced as a pleasurable and cozy environment" ( p.2430. Allen [7] states that, "There's no direct English translation, but there are regional equivalents such as the Swedish 'mys' (and) the Dutch 'gezelligheid"' (para.5). Koselig is most often connected to the Danish word, "hygge" [8, para.7]. These words do not just connect to making just cozy environments, as "it's also (about being) interpersonally cozy, so having a few people with you talking about issues and things you care deeply about...Feeling safe and content."' [11, para.4]. 
Koselig is a way of thinking that originated in Scandinavian countries where winters are long and cold. Countries who adopt the 'kos' mindset view winter as something to be enjoyed. Goldhill [11] explains, "If you think those living in the American northeast have it bad, then spare a thought for the people of Scandinavia. Winter in these countries is especially cold and bleak, with long hours of darkness and, in some of the northernmost regions, barely a glimmer of sunlight. And yet, Scandinavians don't seem to feel sorry for themselves-in fact, the countries have some of the highest happiness rates in the world" (para.1\&2). Woolsey [12] notes that, "Koselig" can describe a hug ("Kan jeg gi deg en kos?" or "Can I give you a "hug"?), or a warm greeting ("Koselig å se deg igjen!" or "It was nice to see you again!")" (para.3). Woolsey (2015) further explains that, "the word is most commonly used during the winter, to talk about anything and everything that evokes warm and fuzzy feelings" (para.3).

Norway has been described as having a home centred culture [10] Garvey [12] posits that, "Norway lacked a developed pub or restaurant culture, so there were few outlets for meeting people except within the home ... Therefore it may appear counter-intuitive to examine the home, the private sphere, as an instrument of social participation, especially in view of the 'homecentredness' with which many Norwegians are attributed." (p.242). It is interesting to think that the private home is a key play to connect socially with others. Is it plausible to imagine that when students do not feel koselig at home, elementary teachers can successfully create a home-like culture in their classrooms - particularly for students who may come from less than ideal homes?

Teachers in this study seemed to employ gestures and strategies that, when combined, created a feeling of "koselig" or "hygge" in their classroom. Teachers continuously stressed the importance of creating a happy home-like atmosphere in their classroom, continuously seeking out methods to meet the social and emotional needs of each of their students. Teachers shared how they attempted to warmly greet and interact with children early in the day, making great efforts to impress upon the young learners that they were noticed, cared for, and valued. Names of children and photographs were prominently displayed throughout the classroom, and even "grandma brag books" were made. Teachers stressed the necessity of touch as a powerful tool for connecting. In short, teachers took great effort in making their classroom feel cozy. This seemed especially important for students who might come from homes that, like winters in Norway and Canada, tend to be cold and harsh.

One surprise that I found in this study connects to creating a cozy home-like atmosphere was when some teachers spoke about having dogs visit their classrooms. The positive effects that dogs can have on the well-being of people should not be dismissed. Wells [13] found that many of the aforementioned benefits were found for all people, stating, "The dog should not be regarded as a panacea for ill-health in humans (p.152). Nonetheless, the findings from this overview [13] suggest that this particular companion animal can contribute to a significant degree to our well-being and quality of lives." (p.152). CrowleyRobinson, Fenwick, and Blackshaw [14] concluded that, "companion animals appear to enhance the lives of their human companions in many ways. Within the family, they love and accept their human companions unconditionally, they can facilitate communication and social interaction, they can provide an appropriate outlet for stress by serving as a diversion from the trials and tribulations of our busy lives, and they fulfill emotional and social support needs" (p.137). The potential that dogs can have to help children connect in schools is promising. For example, Martin and Farnum [15] stated, "Results show that children exhibited a more playful mood, were more focused, and were more aware of their social environments when in the presence of a therapy dog" (p.657).

\section{Limitations}

There are a number of limitations to my study that need to be identified. Relatively speaking, this was a small study with only eight participants from one school division. The study might have benefited from having more teachers from several school divisions participate.

Second, only six of 8 participants were able to attend the first large group think tank. Ideally I think it might have been best if all eight participants could have been together for at least one of the think tank sessions.

Third, the think tank sessions were spread out over several weeks. It might have been beneficial to have had all think tank sessions occur during the course of a school week or weekend, where topics could be immediately revisited and expanded upon.

Fourth, it might have been beneficial to have had a research assistant attend the think tank sessions. While I found a volunteer assistant to assist me in identifying themes, a research assistant could have produced notes and observations from the sessions that were different from mine.

Finally, perhaps it would have been beneficial to bring participants together at the conclusion of the think tank sessions and review emerging themes. This was not possible but may have proven to be helpful. 


\section{Conclusion}

Several significant recommendations emerged at the conclusion of the study. Related to the theme of connecting with their students like caring family members, I highlight three recommendations.

First, teachers should be provided with more opportunities to learn about the complex nature of "family", and how best to make positive relations with student's caregivers. They should also have the opportunity to learn more about the concepts of 'koselig' and 'hygge', and how to incorporate them into their classroom practices.

Second, I recommend that school divisions consider exploring ways to financially support teachers through partial reimbursements or a cost sharing initiative for work-related usage. Communication policies should be reviewed and updated to contend with privacy and safety issues related to written text communication. I recommend that secure communication apps be explored and considered so that teachers do not feel pressure to provide families with personal cell phone numbers.

Third, schools should further explore the possibilities of having therapy or visiting dogs in all of their schools, so that students who may need it have opportunities to connect with them. Teachers in this think tank insisted that even brief interactions with dogs socially, emotionally, and academically benefited their students and their colleagues. This claim seems to be supported by research $[13,14,15]$, and further research should be conducted to see its effects on children.

\section{References}

[1] N. S. Nasir, A. Jones, and M. McLaughlin, "School Connectedness for Students in Low-Income Urban High Schools", Teachers College Record 113(8), 2011, pp. 1755-1793.

[2] H.A. Davis, "The Quality and Impact of Relationships Between Elementary School Students and Teachers", Contemporary Educational Psychology 26(4), 2001, pp. 431-453.

[3] B.K. Hamre and R.C. Pianta, "Student-Teacher Relationships", In G. G. Bear and K. M. Minke (Eds.), Children's Needs III: Development, Prevention, and Intervention, (pp. 59-71), National Association of School Psychologists, Washington, DC, US, 2006.

[4] J.A. Baker, "Contributions of Teacher-Child Relationships to Positive School Adjustment During Elementary School", Journal of School Psychology 44(3), 2006, pp. 211-229.

[5] Government of Alberta. Alberta Occupational Profiles: Secondary School Teacher, 2013, Retrieved from http://alis.alberta.ca/occinfo/content/.
[6] L. Caliva, and I. Scheier, "The Think Tank Technique", The Center for Creative Community, 1992, Retrieved from http://academic.regis.edu/volunteer/ivan/ sect03/sect03b. Htm.

[7] D.G. Allen, "Why are Norwegians So Happy? In a Word: 'Koselig'", 2019, Retrieved from https://www.cnn.com/2019/04/30/health/norway-koselighygge-cozy-nature-chasing-life-wisdom-project/index. html.

[8] D. Nikel, "A Visual Guide to Koselig", 2015, Retrieved from https://www.lifeinnorway.net/a-visualguide-to koselig/.

[9] "“Kos' is Norwegian for Having a Good Time”, n.d., Retrieved from: https://www.visitnorway.com/about/kosmeans-having-a-good-time/

[10] P. Garvey, "How to Have a 'Good Home': The Practical Aesthetic and Normativity in Norway", Journal of Design History 16(3), 2003, pp. 241-251.

[11] O. Goldhill, "The Untranslatable Scandinavian Words for Coziness Describe a Very Particular Winter Joy", 2016, Retrieved from: https://qz.com/601561/ scandinaviansuntranslatable-word-for-winter-coziness-might-explainwhy-theyre-they-happiest-people-on-earth/.

[12] B. Woolsey, (2015), "How Norwegians Stay Happy During Long, Brutal Winters", 2005, Retrieved from: https://www.thrillist.com/lifestyle/nation/a-guide-to-kose lig-the-norwegian-concept-that-helps-prevent-wintertimedepression.

[13] D. Wells, "Domestic Dogs and Human Health: An Overview", British Journal of Health Psychology 12, 2007, pp. $145-156$.

[14] P. Crowley-Robinson, D.C. Fenwick, and J.K. Blackshaw, "A Long-Term Study of Elderly People in Nursing Homes with Visiting and Resident Dogs", Applied Animal Behaviour Science 47(1-2), 1996, pp. 137-148.

[15] F. Martin, and J. Farnum, "Animal-Assisted Therapy for Children with Pervasive Developmental Disorders. Western Journal of Nursing Research 24(6), 2002, pp. 657670. 